\title{
Jesuits and Social Justice
}

\author{
Daniel Cosacchi \\ Marywood University \\ dcosacchi@marywood.edu
}

\begin{abstract}
This article examines the history of social justice ministries within the Society of Jesus. Despite the fact that the term is fraught by a great disagreement both about its meaning and its place within Jesuit apostolates, successive Jesuit general congregations have upheld its importance over the last five decades. Even though what we now consider to be social justice has been a part of Jesuit life since the order's founding, this paper primarily considers the period 1974-present, so as to coincide with GC 32 (1974-75). Social justice has taken many forms, based both on geography and personal interests of the particular Jesuit in question. The broad term covers issues such as the Jesuit Refugee Service, the Plowshares Movement, justice in higher education, and Homeboy Industries. Finally, the paper concludes by considering two growing edges for the order regarding social justice: the role of women in Jesuit apostolates, and the ecological question.
\end{abstract}

\section{Keywords}

Jesuit social justice - Catholic social teaching - peacemaking - ecology - General Congregation 32 - Pedro Arrupe - Jesuit Refugee Service - inculturation

It would be challenging to identify a topic more fraught with controversy in Jesuit studies than the issue of social justice. ${ }^{1}$ Merely defining the term would be problematic in the company of even a small group of Jesuits. Nevertheless, the theme has been important - in one guise or another-in the history of the Society, even from the days of the order's founding. Moreover, social justice has

1 I wish to thank Julia Cosacchi and Kevin Ahern for reading this essay and providing helpful comments and suggestions.

(C) DANIEL COSACCHI, 2019 | DOI:10.1163/22141332-00604005

This is an open access article distributed under the terms of the prevailing CC-BY-NC license at the time of publication. 
been a significant lens through which the Society has framed its mission in the postconciliar period (1965-present), especially with the documents of General Congregation 32 (1974-75). According to at least some scholars, the term "social justice" was first introduced and used by a Jesuit: Luigi Taparelli d'Azeglio $\left(1793^{-1862)}\right.$ in $1840^{2}$ In this essay, I will proceed by first examining Jesuit history and some of the foundational documents of the order that concern social justice. Where did this initiative come from? Why did some Jesuits disagree with a newfound concern for justice in the last half-century? I will examine some key Jesuits who have integrated the issue of social justice into their years in ministry but cannot exhaust even the geographical areas impacted by Jesuit ministry in social justice. In a concluding section, I will examine where Jesuits might go from here.

The definition of social justice, while being controversial, is not entirely elusive. For the purposes of this essay, I will proceed using a variety of descriptions of social justice, while appreciating the various nuances of them all. The description of social justice proffered by the Catechism of the Catholic Church is: "Society ensures social justice when it provides the conditions that allow associations or individuals to obtain what is their due, according to their nature and their vocation." ${ }^{3}$ Moreover, the Catechism continues, "Respect for the human person entails respect for the rights that flow from his dignity as a creature. These rights are prior to society and must be recognized by it. They are the basis of the moral legitimacy of every authority."4 Based on these descriptions of social justice, it is clear that the theme has importance in the church's understanding of human rights and human dignity.

Social justice is also a topic that is firmly based in philosophical foundations. However, it is by no means a univocal term. As David Miller notes, "In the writings of most contemporary political philosophers, social justice is regarded as an aspect of distributive justice, and indeed the two concepts are often used interchangeably." ${ }^{n}$ Distributive justice has to do with ensuring that

2 Joseph Zajda, Suzanne Majhanovich, and Val Rust, "Education and Social Justice: Issues of Liberty and Equality in the Global Culture," in Education and Social Justice, ed. Joseph Zajda, Suzanne Majhanovich, and Val Rust (Dordrecht: The Netherlands: Springer, 2006), 1-12, here 1 .

3 Catechism of the Catholic Church, second ed. (Vatican City: Libreria Editrice Vaticana, 1997), no. 1928. It is worth noting that while the Catechism summarized these teachings, they are not new; they are rooted in the teaching of Thomas Aquinas (1225-74), drawing on classical sources.

4 Catechism of the Catholic Church, no. 1930.

5 David Miller, Principles of Social Justice (Cambridge, MA: Harvard University Press, 1999), 2. Miller uses as his primary example the most prominent thinker on the topic of justice, John 
members of the political order (and indeed all groups) have what is due them. As Miller explains, however, this definition rests on what people consider to be fair or unfair. ${ }^{6}$ Social justice may sometimes be at odds with our own individual good. However, as John Rawls argues, "We cannot preserve a sense of justice and all that this implies while at the same time holding ourselves ready to act unjustly should doing so promise some personal advantage. A just person is not prepared to do certain things, and if he is tempted too easily, he was prepared after all. ${ }^{7}$ At any rate, what is essential in defining social justice is also understanding that the question of social justice is a matter of concrete areas of justice and injustice that must be addressed: the gap between rich and poor, international debt, oppression, violence, disarmament, justice for women, racism, human rights, the population explosion, ecology, refugees, unemployment, an alternative model of development, and justice in the church. ${ }^{8}$

At the risk of understatement, however, not all people agree with the above position about the synonymous nature of these terms. As David Hollenbach, S.J. (b.1942) summarizes the position of modern Catholic social teaching, there are three types of justice: commutative, distributive, and social. ${ }^{9}$ While commutative justice deals with relations between two individuals or private groups and distributive justice expresses the belief that all people have some claim on goods that are meant for public consumption, social justice has overlapping dimensions with these but is distinct from them..$^{10}$ As Hollenbach observes,

Social justice concerns institutionalized patterns of mutual action and interdependence that are necessary to bring about the realization of distributive justice. Within the Roman Catholic ethical tradition, social justice has a meaning somewhat more technical than that in contemporary common usage. It refers to the obligations of all citizens to aid in the

Rawls, who uses the terms "justice," "distributive justice," and "social justice" synonymously in his classic, A Theory of Justice (269n1). Also see Tom L. Beauchamp, "Distributive Justice and the Difference Principle," in H. Gene Block and Elizabeth H. Smith, eds. John Rawls' Theory of Social Justice: An Introduction (Athens, OH: Ohio University Press, 1980), 135-36.

6 Beauchamp, "Distributive Justice," 61.

7 John Rawls, A Theory of Justice, rev. ed. (Cambridge, MA: Harvard University Press, 1999), 498.

8 See Donal Dorr, The Social Justice Agenda:Justice, Ecology, Power and the Church (Maryknoll, NY: Orbis Books, 1991), 7-41.

9 David Hollenbach, Justice, Peace, and Human Rights: American Catholic Social Ethics in a Pluralistic World (New York: Crossroad, 1988), 26.

10 Hollenbach, Justice. 
creation of patterns of social organization and activity that are essential both for the protection of minimal human rights and for the creation of mutuality and participation by all in social life. In other words, social justice is a political virtue. It is distinguished from the other forms of justice because it is based on that form of human interdependence which occurs through the state. Citizens have a personal obligation, mediated through political obligation, to help create a society in which the concerns of agape can be made effective, namely concerns for concrete needs of all persons and for the creation of reciprocal interdependence. Social justice also states the obligation of the state both to promote distributive justice and to make those legal claims on all citizens that are entailed by this task. $^{11}$

Pope Pius XI (r.1922-39) first used the concept of social justice in the Catholic magisterium. As Kenneth Himes notes, for Pius, social justice "became the principle of social governance which guaranteed that each entity within a society would receive the appropriate freedom and resources to perform its task and thereby build up the common good."12 As a religious order in the church, the Society of Jesus has taken social justice as most important in its own ministries within the body of Christ. This importance has a place not only among members of the order themselves, but also among the larger global community as a whole. The work of Jesuits toward creating a more just society is meant to have the effect of creating conversions in each individual person. This has been a foundational part of the order since its founding. To these foundations I now turn.

When St. Ignatius Loyola (c.1491-1556) and his companions founded the Society of Jesus in 1540, the terminology "social justice" would have been altogether foreign to the brethren. On the contrary, "works of mercy" or "works of charity" would have been not only well known, but also considered customary among the first Jesuits. While many would hesitate today to speak of works of mercy in the same breath as works of justice, there is certainly a long tradition in the church of the integral connection between the two, which, as St. Thomas

\footnotetext{
11 Hollenbach, Justice, 27.

12 Kenneth R. Himes, O.F.M., Responses to 101 Questions on Catholic Social Teaching (New York-Mahwah, NJ: Paulist Press, 2001), 44.
} 
Aquinas explains, "exist in all God's works."13 Even though reading social justice into Ignatius's Spiritual Exercises would surely be anachronistic, it must be said that themes exist in those pages that would identify Ignatius and his companions as religious people who were striving for the good of all. In fact, Ignatius was intimately familiar with scholastic discussions of contributive and distributive justice. Former superior general of the Society of Jesus, PeterHans Kolvenbach (1928-2016), pointed directly to the key Ignatian tenet of finding God in all things as the lynchpin of finding social justice themes in the Spiritual Exercises. ${ }^{14}$ The result of finding God in all things is a clear union between prayer and action in the Ignatian worldview. As one theologian writes, "Action brings one into contact with the realities of social sin-the oppressive social structures of one's culture and society - and through one's contemplative union in God a person can judge the truth or error of the values one confronts." ${ }^{15}$

The first Jesuits made works of mercy part of their daily labors in the church. As John W. O'Malley, S.J. (b.1927) recognizes, in relying on the Formula text of Jerónimo Nadal (1507-80), "the fact that he on one occasion pronounced that the Jesuits were fundamentally engaged in a 'ministry of reconciliation' is important for understanding the other ministries and their strongly social character."16 What follows in O'Malley's account is the sometimes-incredible success that the early Jesuits had in bringing harmony where there was once warfare, division, and discord. ${ }^{17}$ O'Malley explains, "As early as 1540, [Claude] Jay reported that through preaching and hearing confessions in Bagnorea, fifty miles north of Rome, he was able to convince the villagers to renounce the bloody feuds that had raged there for years." ${ }^{18}$ In the twenty-first century, it is unlikely that such sacramental actions on the part of the Jesuits would be

13 St. Thomas Aquinas, Summa teologica, transl. Fathers of the English Dominican Province (New York: Benziger Bros., 1948), I. q. 21.

14 See Peter-Hans Kolvenbach, S.J., The Road from La Storta: Peter-Hans Kolvenbach, S.J., on Ignatian Spirituality (St. Louis, MO: Institute of Jesuit Sources, 200o), 243. The text of this chapter came from a lecture Kolvenbach originally delivered at Our Lady of Lourdes Church, Toronto, on November 1, 1998. The lecture, and chapter, is entitled, "Social Justice and the Spiritual Exercises of St. Ignatius of Loyola."

15 Susan Rakoczy, I.H.M., Great Mystics and Social Justice: Walking on the Two Feet of Love (New York: Paulist Press, 2006), 64.

16 John W. O'Malley, The First Jesuits (Cambridge, MA: Harvard University Press, 1993), 169.

17 Although, in fairness, O'Malley notes that the Jesuits could have sometimes exaggerated their effectiveness in recounting these stories of peacemaking. See O'Malley, First Jesuits, 169 .

18 O'Malley, First Jesuits, 169 . 
considered strictly social justice works, yet the motivation and the result stand strongly in favor of considering them to be precisely such a ministry. Even from the first days of the Society, there could be no strict separation between preaching the gospel and working for peace.

In addition to their work in peacemaking from the earliest days, the Jesuits have always been concerned with a special ministry to the poor and outcast, the sick and the imprisoned. ${ }^{19}$ In a very particular way, the Jesuits have always been interested in the issue of fair loan repayment. Also, as O'Malley recounts, the earliest Jesuits "sometimes successfully intervened to have the sentences of convicted criminals mitigated, and on a few occasions they got the death penalty suspended and the prisoner freed."20 But why were these types of ministries so important for the early Jesuits? Part of the answer to that question rests on the fundamental charism of the order in the spiritual tradition of Ignatius. As Joseph de Guibert, S.J. (1877-1942) explains, the Scripture had such a profound impact on Ignatius that it was impossible to disregard the call to serve both God and human beings. De Guibert writes that through Ignatius's "devotion to the mysteries of the Gospel, and by his tender piety toward the humanity of Christ, he simply inserted himself in the great medieval current of devotion to this holy humanity."21 In one sense, Ignatius was falling in line with the pious practice that he inherited as a Christian. In another sense, though, his endeavor was also novel. De Guibert continues, describing Ignatius inheriting these medieval mindsets and practices: "In some highly personal fashion he absorbed this already long tradition into himself. Then he drew from it in order to add something more concrete and attractive to his own thoughts about service of God and conformity to His will."22 Or, as it has come to be known, Jesuits are themselves, and train their students to be, "contemplatives in action."23

\subsection{Saint Alberto Hurtado (1901-52)}

One of the perennial controversies surrounding ecclesial ministries of social justice is the relationship between justice and charity. In a particular way, before GC 32 , the two themes often collided in the works of organizations and individuals. Included among the latter group would be Alberto Hurtado, S.J.,

19 The early Jesuits were well known for their work in hospitals and prisons, ministry to the dying, and ministry to prostitutes. For more on this, see O'Malley, First Jesuits, 171-85.

20 O'Malley, First Jesuits, 174.

21 Joseph de Guibert, S.J., The Jesuits, Their Spiritual Doctrine and Practice: A Historical Study, ed. George E. Ganss, trans. William J. Young, S.J. (Chicago: Institute of Jesuit Sources, 1964), 181.

22 de Guibert, Jesuits, 181.

23 See William A. Barry, S.J., and Robert G. Doherty, S.J., Contemplatives in Action: The Jesuit Way (New York-Mahwah, NJ: Paulist Press, 2002). 
canonized by Pope Benedict XVI (r.2005-13) on October 23, 2005. ${ }^{24}$ According to John Gavin's examination of Hurtado's life and ministry, the Chilean Jesuit "believed that the struggle for a just social order, rooted in Christian principles, gave witness to this truth and, through the grace of Christ, invested the natural with the supernatural gift of charity" 25 Hurtado spent a great deal of time working in Catholic Action, trying to make it "a true spiritual movement that would take on the debilitating problems in Chilean society." 26

As Gavin notes, both in the text of his article and in its very title, Hurtado believed that "true charity begins where justice ends."27 This is a difficult topic to encounter in the church, because there are two ideological sides on this issue. One side claims that charity is a morally superior virtue to social justice. Another group would maintain that working for social justice is more important than works of charity, because the latter is simply taking pity on the recipients of the charity, whereas the former would carry out a shift in the societal wellbeing. ${ }^{28}$ For Hurtado, however, there was some middle ground: "While Hurtado certainly did not deny the superiority of charity as a supernatural gift, he did emphasize that charity separated from justice was not authentic charity." 29 This middle ground could well be considered a forerunner to the deliberations and final documents produced in the Jesuit general congregation which took place some two decades after Hurtado's death. His saintly life and ministry were a precursor to a sense of social justice in the Society of Jesus that matured to become a central component of the Jesuit charism since in the last part of the twentieth century.

\section{$1.2 \quad$ General Congregation 32 (1974-75)}

Even if the foundation of the Jesuits had some interest in matters that could later be termed "social justice," there is no question that the issue has experienced an overt renaissance in the time since the Society's General Congregation(GC)

24 For a biographical overview of Hurtado's life, see Joseph N. Tylenda, S.J., Jesuit Saints and Martyrs: Short Biographies of the Saints, Blessed, Venerables, and Servants of God of the Society of Jesus (Chicago: Loyola Press, 1998), 251-53.

25 John Gavin, S.J., “True charity begins where justice ends': The Life and Teachings of St. Alberto Hurtado, S.J.," Studies in the Spirituality of Jesuits 43, no. 4 (2011): 1-39, here 7.

26 Gavin, "True charity," 9.

27 Gavin, "True charity," 31.

28 For three helpful treatments of this issue through the lens of Pope Benedict Xvi's encyclical letter Deus caritas est, see Charles M. Murphy, "Charity, Not Justice, as Constitutive of the Church's Mission," Theological Studies 68, no. 2 (2007): 274-86; Richard Ryscavage, S.J., "Bringing Back Charity," America 194, no. 9 (2006): 14-16; and Thomas J. Massaro, S.J., "Don't Forget Justice," America 194, no. 9 (2006): 18-20.

Gavin, "True charity," 31. 
32, which took place December 2, 1974- March 7, 1975. In point of fact, the former superior general of the Society of Jesus, Peter-Hans Kolvenbach, called the dual commitment to faith and justice in the Society of Jesus "new in 1975." 30 This meeting was the Jesuit response to Vatican II. While GC 32 is significant, it must be said that the Jesuits were not alone in their turn towards social justice. Other religious orders, especially communities of women religious, took the impetus of Vatican II vis-à-vis social justice, and ran with it. Without a doubt, the part of those GC 32 documents that has become the most well-read and significant is its Decree 4: "Our Mission Today: The Service of Faith and the Promotion of Justice." ${ }^{31}$ These words themselves have become a key catchphrase at most Jesuit-run high schools and colleges/universities in the United States. Simply perusing the websites of such institutions will lead to any number of allusions to this relatively recent turn of phrase in Jesuit lingo. But what is the payout of this shift in the Jesuit worldview?

The final text of Decree 4, however, was not a unanimous appeal in favor of a major shift in the Society's apostolic priorities. Rather, it was a compromise between two competing factions in the Society at the time of GC $32 .{ }^{32}$ As excerpts from the official minutes of $\mathrm{GC}_{32}$ indicate, the time leading into the congregation itself included no little dissension among the ranks of Jesuits from around the world, evidenced by the varying replies in the pre-congregational postulata that Jesuits were instructed to prepare: "Among the six topics which received a majority of votes were 'the criteria of our apostolic service today' (first place) and 'the promotion of justice' (fourth place)." ${ }^{33}$ Such disagreements necessitated the Society's leadership to make a decision regarding GC 32's priorities. As the minutes go on to indicate, "When the Congregation came to deciding on a 'first priority' some proposed that we should take these two topics together, and that is what the Congregation did."34 This difference of opinion held by individual Jesuits on the priorities of the Society's future is emblematic of a

30 See Peter-Hans Kolvenbach, S.J., "The Service of Faith and the Promotion of Justice in American Jesuit Higher Education," in A Jesuit Education Reader, ed. George W. Traub, S.J. (Chicago: Loyola Press, 2008), 144-162, here 145.

See John W. Padberg, S.J., ed., Jesuit Life and Mission Today: The Decrees of the $37^{\text {st }}-35^{\text {th }}$ General Congregations of the Society of Jesus (St. Louis, MO: Institute of Jesuit Sources, 2009), 298-316.

For the best historical account of what took place surrounding GC 32, see John W. Padberg, S.J., Together as a Companionship: A History of the Thirty-First, Thirty-Second, and Thirty-Third General Congregations of the Society of Jesus (St. Louis, MO: Institute of Jesuit Sources, 1994), 29-103.

33 Padberg, Jesuit Life and Mission Today, 265.

34 Padberg, Jesuit Life and Mission Today, 265. 
larger-scale disagreement, which I will discuss in greater detail below. As it stands, though, Jesuit understanding of the mutually enhancing relationship between faith and justice is characterized by principles from Decree 4.

In a general, overarching way, Decree 4 was the Jesuit response to a larger shift that had been taking place in the universal church. With the promulgation of Pope Paul vi's (r.1963-78) social encyclical Populorum progressio some seven years earlier in 1967 , the Society of Jesus recognized the need to examine their communal relationship with social justice. In Populorum progressio, Paul made it clear that the church's work for social justice is not only meant for certain sectors of the church, but for the entire church. ${ }^{35}$ While it would be impossible in this limited space to focus on each of the themes that arise in Decree 4, I wish to highlight five-one from each section of the decree-to illustrate how the Society integrated magisterial teaching into its own self-understanding. ${ }^{36}$ I do this because these five components are essential for any understanding of the subsequent years of Jesuit ministry infused by social justice.

The first of the major components from Decree 4 is "a thoroughgoing reassessment of our traditional apostolic methods, attitudes and institutions" (9). ${ }^{37}$ Such a reassessment holds in connection the demands of the Gospel and the particular context in which each individual Jesuit finds himself. The fathers go on to claim that the Gospel "demands a life in which the justice of the Gospel shines out in a willingness not only to recognize and respect the rights of all, especially the poor and powerless, but also to work actively to secure those rights" (18). In the Jesuits' new understanding of their mission in the world, there is no sense that their priestly charism should exempt them from direct service in the cause of bringing about justice for all peoples; on the contrary, their lives in the priesthood ought to bring them closer to concrete work towards a more just society. Such lives also find each Jesuit "in need of being evangelized" (23).

The second component from Decree 4 is the realistic understanding of the challenges the Society faces. Among the most prominent of these challenges was the frustrating realization that, "It is now within human power to make

35 For a helpful overview of this phenomenon, especially a comparison of Populorum progressio with later social encyclicals (and further shifts in ecclesiology concerning the relationship of faith and justice), see Kevin Ahern, "The Justice Legacy of Populorum progressio: A Jesuit Case Study," Journal of Moral Theology 6, no. 1 (2017): 39-56.

36 For another reading of Decree 4, see Francisco Ivern, S.J., "The Future of Faith and Justice: A Critical Review of Decree Four," Studies in the Spirituality of Jesuits 14, no. 5 (1982): 1-30.

37 Hereafter, when citing from Decree 4, I will note the paragraph number from the decree, in Padberg's collection. 
the world more just-but we do not really want to. Our new mastery over nature and man himself is used, often enough, to exploit individuals, groups, and peoples rather than to distribute the resources of the planet more equitably" (27). Even from the founding of the order, as I noted earlier, the Jesuits have been interested in the justice that focuses especially on the plight of those who have been suffering. In this natural progression of thought, the delegates of GC $3^{2}$ make it clear that all of creation is entitled to an equal share in the riches of the earth.

The third of the components from the Decree concerns making practical decisions for the apostolic work of Jesuits in the world today. As the delegates write, "For us, the promotion of justice is not one apostolic area among others, the 'social apostolate'; rather, it should be the concern of our whole life and a dimension of all our apostolic endeavors" (47). This is crucial for the Jesuits since it means that their work in ministry must always be in solidarity with the poor in society. Whereas it once might have been possible to envision a Jesuit working in a "social apostolate" as an outlier in the society, following GC 32 , all Jesuits were expected to attend to the realities of social justice (and social injustice) in everything they did throughout their ministries. One concrete way to carry out this shift would be to focus on theological research concerning social justice, converting "those who have power to bring about social change," focusing especially on formation, and communicating these ideals with clarity (6o).

The fourth key element that is now a driving force of the Society of Jesus is that the order is a "missionary body." In this point, the role of the local superior of a Jesuit community is essential in order to bind together individual Jesuits within that nuclear community. Furthermore, the local community finds itself as a part of the regional province as well as of the universal Society of Jesus (68). This is important because the mission of an individual Jesuitinfused with the newfound understanding of social justice and solidarity with the poor-must be seen in tandem not only with his local community members, but also with his confreres in the province and around the world. In so envisioning the order, it is clear that work for "the service of faith and the promotion of justice" is not only a global theme, but also a local reality in each individual Jesuit.

The fifth key component of Decree 4 concerns the "practical dispositions" of Jesuits. Of course, in the case of Jesuits who have been trained in discernment, these practical dispositions will come about through an intense period of prayer regarding a decision that will be made for the ministry of each man. The delegates explain further, "The process of evaluation and discernment must be brought to bear principally on the following: identification and analysis of the problems involved in the service of faith and the promotion of justice and the review and renewal of our apostolic commitments" (74). The individual act 
of discernment, while it remains a very personal and sacred process for each Jesuit, is now even more exhaustive because it involves how that Jesuit can use his personal gifts and talents within his given ministerial duties to fulfill his role in bringing about justice in society.

While the content of Decree 4 has altered all Jesuit ministries, it would be impossible to ignore the controversies that resulted from the promulgation of that decree. In particular, in his letter of May 2, 1975, then Cardinal Secretary of State Jean Villot (in office 1969-79) writes to the then superior general of the Society of Jesus, Pedro Arrupe: "While some statements in the decrees merit total acceptance, others are somewhat confusing and could, because of the way they are expressed give grounds for misinterpretation."38 In an appendix to the letter, which he requested to be published along with the decrees, the secretary of state (writing in the name of Pope Paul vi), made two interesting points:

The priest should inspire lay Catholics, since in the promotion of justice theirs is the more demanding role. The tasks proper to each should not be confused. It is also helpful to recall that work for the promotion of justice should be undertaken in accord with directives drawn up by the local hierarchy and in consideration of the conditions peculiar to each region. ${ }^{39}$

There is little doubt that the Holy See had some issue with Decree 4. In particular, it was clear that they wanted to maintain a clear distinction between the ordained and lay states. While there are clear canonical differences, the insistence on this point seems odd. Furthermore, Villot wanted to identify the local ordinary as the individual who would determine what social justice would look like in his diocese. However, while Jesuits are expected to have cordial relationships with their local bishops, there is not an expectation of obedience to him in the same way as there is expected obedience to that Jesuit's legitimate provincial superior.

Dissent from Decree 4 was not limited only to the Vatican, however. As I noted above, Jesuits themselves were divided on whether the words of the decree were, in fact, appropriate for their state of life. During GC 32 itself, Spanish, Dutch, and American delegates had to be appeased so as not to "create a separate province." ${ }^{40}$ As Martin R. Tripole, S.J., noted in his research of

38 "Letter of the Cardinal of State to Father General," in Padberg, Jesuit Life and Mission Today, 396-99, here 396.

39 Padberg, Jesuit Life and Mission Today, 398.

40 Jean Lacouture, Jesuits: A Multibiography, trans. Jeremy Leggatt (Washington, D.C.: Counterpoint, 1995), 465-66. 
interviews with other Jesuits after GC 32 , "The fact is the document has not ceased to cause confusion and division since the time of its promulgation." ${ }^{41}$ One of the most prominent Jesuits of the twentieth century, Cardinal Avery Dulles (1918-2008), was one of the Jesuits who believed that the word "justice" in Decree 4 was "vaguely used." ${ }^{2}$ Dulles's issues with the use of "justice" in Decree 4 likely have grounding in his understanding of biblical justice. He contends, "it is most difficult, or rather impossible, to deduce any specific social or political philosophy from occasional dicta of Jesus or the apostles." 43 This, it would appear, is in marked contrast to Decree 4. Dulles, though, is not alone among Jesuits in responding with confusion to the Decree. In his interviews with some 15 Jesuits, 12 of whom had been delegates at GC 32, Tripole first asked what the meaning of justice was in the decree. He reports, "The most common answer was 'I don't know.' And the second most common answer consisted of words to that same effect." ${ }^{44}$ All of these points notwithstanding, however, it is clear that the Society of Jesus as a body is most committed to promoting the clear relationship between faith and justice in all of its ministries. ${ }^{45}$ This is reaffirmed in later general congregations. While there is certainly some dissension among the Jesuit brethren, they are "far from being as divided and incoherent as critics, especially Jesuit critics, maintained." 46 In the next part of this essay, I will examine various particular examples of how Jesuits have gone about making this relationship clear.

\section{Key Examples, 1975-Present}

Because Decree 4 was interested not so much in the general idea of creating systems of justice (although it did focus to some extent on general systems of social justice), but more so in forming individual Jesuits who would

41 Martin R. Tripole, S.J., Faith Beyond Justice: Widening the Perspective (St. Louis, MO: Institute of Jesuit Sources, 1994), 7.

42 Avery Dulles, S.J., "Faith, Justice, and the Jesuit Mission," in Assembly 1989: Jesuit Ministry in Higher Education (Washington, D.C.: Jesuit Conference, 1990), 19-25, here 21.

43 Avery Dulles, S.J., "The Meaning of Faith Considered in Relationship to Justice," in The Faith That Does Justice: Examining the Christian Sources for Social Change, ed. John C. Haughey, S.J. (New York: Paulist Press, 1977), 10-46, here 42.

44 Tripole, Faith Beyond Justice, 9.

45 For a helpful overview of this debate, see Kevin Ahern, Structures of Grace: Catholic Organizations Serving the Global Common Good (Maryknoll, NY: Orbis Books, 2015), 56-62.

46 John W. O’Malley, S.J., The Jesuits and the Popes: A Historical Sketch of Their Relationship (Philadelphia: Saint Joseph's University Press, 2016), 108. 
be working for justice in their own ministries, it is imperative to examine the Jesuit struggle for "the service of faith and the promotion of justice" through the lens of important individual members of the Society who have fulfilled the delegates' vision as it is first laid out in GC 32 , and later reaffirmed by other congregations.

\subsection{Pedro Arrupe (1907-91) and the Jesuit Refugee Service}

Without question, the single most influential Jesuit in the area of social justice in the last forty years has been Pedro Arrupe, who served as the twenty-eighth superior general of the order from 1965 to 1983 . In what was undoubtedly a precursor to Decree 4 of GC 32, Arrupe delivered a now-infamous address in Valencia, Spain to European Jesuit alumni on the liturgical feast of Saint Ignatius Loyola, July 31, 1973. The address, originally entitled "Men for Others," ${ }^{47}$ laid the groundwork for much of what the GC 32 delegates would write in Decree $4{ }^{48}$ As far as Arrupe was concerned, there was one pressing question that he posed to his audience as a confrontation to his own order:

Have we Jesuits educated you for justice? You and I know what many of your teachers will answer to that question. They will answer, in all sincerity and humility: No we have not [...]. We must help each other to repair this lack in us, and above all to make sure that in the future the education imparted in Jesuit schools will be equal to the demands of justice in the world. ${ }^{49}$

It was already clear at that time that Arrupe was keen to transform the Society of Jesus into a religious order for whom the pursuit of justice was part and parcel of their work around the world, and which would integrate social justice into existing ministries, such as education.

Perhaps the most direct and longstanding impact of Arrupe's tenure as superior general was his founding of the Jesuit Refugee Service (JRS) ${ }^{50}$ It is clear that, for Arrupe, JRs is a logical outcome of the writings of GC 32. In July, 1979,

47 Arrupe himself later emended the title of the address to be "Men and Women for Others."

48 For more on the specifics of this address, see my essay, "Women and Men For Others: Embodying Love through Nonviolence in Arrupe, Berrigan, and Sobrino," in God Has Begun a Great Work in Us, ed. Jason King and Shannon Schrein (Maryknoll, NY: Orbis Press, 2015): 119-30.

49 Pedro Arrupe, S.J., Justice with Faith Today: Selected Letters and Addresses, ed. Jerome Aixala, S.J. (St. Louis, MO: Institute of Jesuit Sources, 1980), 2:125.

5o See Ahern, "The Justice Legacy of Populorum progressio," 40. 
Arrupe reflected on the general response to GC $3^{2}$ and the reality of Jesuits living directly with the poor and oppressed of the world: "I would like to emphasize that the mere fact of being in a poor nation or region is not the same thing as actually going out and trying to share the life of the people and learn from their experiences and culture."51 This latter type of immersion into the life of a people is a significant part of what JRS aims to do in its own work throughout the world. After nearly forty years, JRS continues its original mission: "by its very nature, JRs is driven by the Jesuits' compassion for the plight of refugees. It is a service for poor and marginalized people often living at the frontiers and on the conflict lines of our world." ${ }^{52}$ As Ronald Modras explains, Arrupe was very clearly affected by concrete circumstances of injustice in the world: "The fall of Saigon in the summer of 1975 prompted tens of thousands of Vietnamese to flee their homes and seek refuge in Thailand or Malaysia, risking their lives on small, rickety wooden boats. Their numbers would be joined by refugees fleeing Laos and Cambodia." ${ }^{53}$

As Kevin Ahern has helpfully articulated, the mission of JRS is threefold: accompaniment, service, and advocacy. ${ }^{54}$ In each of these three components of JRS's mission, there is a hearkening back to the earliest days of the Society of Jesus, just as I indicated earlier with regard to social justice at large. ${ }^{55}$ Even if it would be anachronistic to say that the Jesuits have always been interested in the cause of social justice, the same accusation could never be leveled upon Arrupe or the JRS. For the JRS, during and after Arrupe's tenure as superior general of the Jesuits, social justice has been the foremost concern of the organization. Since its foundational goal to serve only refugees, JRs has expanded, both in size and in scope. ${ }^{56}$ It now serves over half a million people around the world, addressing all areas of fundamental human rights. ${ }^{57}$ As David Hollenbach, S.J. suggests, JRS ought to be used as a model for advancement and

\footnotetext{
$51 \quad$ Arrupe, Justice with Faith Today, 2:311.

$5^{2}$ Peter Balleis, S.J., "Global Human Mobility, Refugees, and Jesuit Education at the Margins," in The Jesuits and Globalization: Historical Legacies and Contemporary Challenges, ed. Thomas Banchoff and José Casanova (Washington, DC: Georgetown University Press, 2016), 224-38, here 233 .

53 Ronald Modras, Ignatian Humanism: A Dynamic Spirituality for the $21^{\text {st }}$ Century (Chicago: Loyola University Press, 2004), 277.

54 See Ahern, Structures of Grace, 49-56.

55 See Kevin O'Brien, S.J., "Consolation in Action: The Jesuit Refugee Service and the Ministry of Accompaniment," Studies in the Spirituality of Jesuits 37, no. 4 (2005): 1-51, here 7-14.

56 See John W. O'Malley, S.J., The Jesuits: A History from Ignatius to the Present (Lanham, MD: Rowman and Littlefield, 2014), 102. 
"how the Jesuits' contributions and their ministries to the universal common good might be enhanced in the years ahead." ${ }^{58}$ To be sure, JRS serves as an exemplary model, not only of Jesuit charism being put into practice, but also of an exceptional organization that may be emulated for the furthering of social justice.

\subsection{Daniel Berrigan (1921-2016), Stephen Kelly (b.1949), and the Plowshares Movement}

If JRS serves as an official Jesuit-sponsored apostolate, then the Plowshares Movement would be an unofficial one. Since the very beginning of that movement on September 9, 1980 in King of Prussia, PA, one Jesuit has been associated with the group that seeks to enact Isaiah's prophecy to "beat swords into plowshares" (Is 2:4).59 That Jesuit, Daniel Berrigan, is one of the most prominent of the twentieth century. Mostly coming to prominence through his actions of nonviolent civil disobedience, Berrigan is best known for the action in which he participated on May 17, 1968: the Catonsville Nine. ${ }^{60}$ Since that time, he has acted in film (The Mission), and has been portrayed in popular songs (Dar Williams, "I Had No Right," and Paul Simon, "Me and Julio Down by the Schoolyard") and novels (Colum McCann, Let the Great World Spin, and Joyce Carol Oates, The Man Without a Shadow). Along with his brother Philip, ${ }^{61}$ Berrigan was featured on the cover of the January 25,1971 issue of Time magazine. ${ }^{62}$ Despite his popular acclaim throughout the late 1960 s and 1970s, Berrigan was also considered an antihero in many American households, and among many of his fellow Jesuits.

While the Catonsville action preceded GC 32 , the vast majority of Berrigan's actions of civil disobedience (including his 1980 Plowshares action) came in the wake of Decree 4. To be sure, the words of that decree, and the new direction of the Jesuits under Arrupe's leadership, were a boon to Berrigan's

58 David Hollenbach, S.J., "The Jesuits and the 'More Universal Good': At Vatican II and Today," in Banchoff and Casanova, eds., Jesuits and Globalization, 169-87, here 180.

59 For more on the movement, see Arthur J. Laffin and Anne Montgomery, eds., Swords into Plowshares: Nonviolent Direct Action for Disarmament (San Francisco: Harper and Row, 1987).

6o See Shawn Francis Peters, The Catonsville Nine: A Story of Faith and Resistance in the Vietnam Era (Oxford: Oxford University Press, 2012).

61 For Berrigan's epistolary relationship with Philip, see Daniel Cosacchi and Eric Martin, eds., The Berrigan Letters: Personal Correspondence between Daniel and Philip Berrigan (Maryknoll, NY: Orbis Books, 2016).

62 Time Magazine 97, no. 4 (January 25, 1971). The feature article is entitled, "Rebel Priests: The Curious Case of the Berrigans." 
public sensibilities. His faithfulness to the Jesuits notwithstanding, Berrigan was unceremoniously expelled from his Jesuit community in New York upon his release from federal prison on February 24, 1972. ${ }^{63}$ This expulsion, though, did not deter Berrigan from believing that his activism was based on the Gospel message of peace, and also on the newly-explicit Jesuit call to social justice.

One of Berrigan's most noteworthy protégés in the Society of Jesus and in the Plowshares movement is Stephen Kelly. ${ }^{64}$ While Kelly never reached the popularity of Berrigan in the mainstream media and popular culture, he has actually spent a considerably longer period of time in jail than his Jesuit elder. Additionally, much of his jail time has been marked by especially heinous conditions brought about by solitary confinement. For Kelly, working for peace is necessary to bring about social justice. As he explained to George Anderson, S.J. in an interview, he experienced a conversion from support for the Vietnam War to absolute pacifism. Kelly continued by explaining, "My hope is that the church will really become a peace church [...]. As for what I'll be doing in the future, as long as nuclear weapons are being made for use on human beings, I'll try to resist their creation." ${ }^{65}$ Kelly's protests and arrests have continued in the twenty years since this interview took place, and he believes that they are at the heart of the Jesuit mission, and in particular the faith that does justice.

\subsection{Kolvenbach, Nicolas, Sosa, and the Next General Congregations $\left(33^{-36)}\right.$}

The four general congregations convoked in the years since 1975 have strengthened individual Jesuits throughout the world enacting the commitments of Decree 4 of GC 32. From September 1 until October 25, 1983, Jesuit delegates met in Rome for GC 33. At the outset of this meeting, the delegates elected Peter-Hans Kolvenbach as Arrupe's successor. Throughout the decrees of GC 33 , no document was cited as often at Decree 4 of GC $32 .{ }^{66}$ The delegates saw their mission as being "sent into today's world." This would be impossible to

63 Berrigan was paroled after eighteen months in federal prison in Danbury, CT. For more on the incident of him being unceremoniously removed from his Jesuit community, see Murray Polner and Jim O'Grady, Disarmed and Dangerous: The Radical Lives and Times of Daniel and Phillip Berrigan, Brothers in Religious Faith and Civil Disobedience (New York: Basic Books, 1997), 262.

64 Kelly preached the homily at Berrigan's funeral Mass, on May 6, 2016 at St. Francis Xavier Church in Manhattan. The text is available online: https://sojo.net/magazine/ august-2016/do-not-be-ruled-fear-faith (accessed September 19, 2019).

65 George M. Anderson, S.J., "A Prisoner for Peace: An Interview with Stephen Kelly," America 179, no. 11 (1998): 14-18, here 18.

66 It is cited ten times in total. 
carry out faithfully without care for a faith that does justice. The delegates stated that they could not be credible witnesses of the gospel without "solidarity with the poor."67 By the time of the January 5 - March 22, 1995 meetings of GC 34 , Kolvenbach was presiding over a worldwide society that had largely overcome much of the turmoil that had impacted it immediately before his term began over a decade earlier. ${ }^{68}$ In particular, Decree 3, entitled "Our Mission and Justice" carries on the work begun some two decades earlier in Decree 4 of GC 32. The delegates remind the brethren, "Some insertion into the world of the poor should therefore be part of the life of every Jesuit."69

Upon the resignation of Kolvenbach as Superior General in 2008, the Society assembled from January 7 - March 6 of that year to elect his successor and promulgate new decrees. They elected Adolfo Nicolás, S.J. (b.1936), who had formerly been the provincial of Japan. While the documents did not address the issue of social justice with the precision and depth of GC 32 and 34, its presence in the text was an underlying reality of the final decrees. Moreover, with a renewed emphasis on intercultural dialogue, the delegates had arrived at confirmation "that faith and justice cannot simply be one ministry among others; they are integral to all ministries and to our lives together as individuals, communities, and a worldwide brotherhood." ${ }^{\prime 0}$ As he arrived at his eightieth birthday, Nicolás followed in Kolvenbach's footsteps by tendering his resignation to the delegates of GC 36, which convened from October 2 - November 12, 2016. At that meeting, the delegates elected Arturo Sosa, S.J. (b.1948) as the thirtyfirst superior general of the Society. The decrees of the most recent general congregation focus, in a very particular way, on the norms of social justice from the Jesuit perspective. ${ }^{71}$ While Decree 4 of GC 32 and Decree 3 of GC 34 are not cited directly, Decree 1 of GC 36 is entitled "Companions in a Mission of Reconciliation and Justice." This title alone shifts the document's center, and couples the two virtues mentioned in the title. The delegates do this primarily because of the influence of their Jesuit confrère, Pope Francis (r.2013-), who is cited frequently in the decree. In a particular way, the Society renews its

$67 \quad$ GC 33, Decree 1, no. 48, in Padberg, Jesuit Life and Mission Today, 454.

68 For details on this transition period, see my obituary of Kolvenbach for America, "Father Peter-Hans Kolvenbach, leader of Jesuits at a tumultuous time, dies at 87" (Nov. 26, 2016); https://www.americamagazine.org/faith/2016/11/26/father-peter-hans-kolvenbachleader-jesuits-tumultuous-time-dies-87 (accessed September 19, 2019).

69 GC 34, Decree 3, no. 17, in Padberg, Jesuit Life and Mission Today, 534.

$70 \quad$ GC 35, Decree 3, no. 4, in Padberg, Jesuit Life and Mission Today, 744-45.

71 The documents are accessible online: http://www.mdsj.org/gc36decrees (accessed June 24, 2016). 
call for social justice to include "reconciliation with creation."72 This type of reconciliation calls for Jesuits to begin "changing our personal and community lifestyles, adopting behaviors coherent with our desire for reconciliation with creation. We must accompany and remain close to the most vulnerable."73

\subsection{Ignacio Ellacuría (1930-89) and the University of Central America}

Perhaps the darkest day in twentieth-century Jesuit history was November 16 , 1989. On that day, many Jesuits (and their lay companions) were shocked by the news that six Jesuit priests, their housekeeper, and her daughter had been brutally murdered at the hands of a battalion squad at the command of the Salvadoran government. In the intervening years, it became clear that these assassins had been trained at the "School of the Americas" in Fort Benning, GA, and so the collusion with the United States had been not only financial, but also tactical in that the killers had been trained by United States military officers. The primary target of the massacre was the rector (president) of the University of Central America (UCA), Ignacio Ellacuría, S.J. His crime had been speaking out for social justice and basic human dignity among the poor and oppressed of El Salvador throughout his entire career as a public intellectual. ${ }^{74}$ Much like Berrigan, Ellacuría's shift to become more a "public personality" led to certain disagreements with other Jesuits, and to a diminished role in Jesuit affairs, which he once had a hand in steering. ${ }^{75}$

An accomplished philosopher and theologian, Ellacuría used his writing and public lecturing to bring light to the inherent connection between the suffering of Christ and the suffering of Salvadorans. ${ }^{76}$ Of course, Ellacuría is not

$72 \mathrm{GC}_{36}$, Decree 1, nos. 29-30. Pope Francis is directly cited thirteen times in Decree 1 alone.

73 GC 36 , Decree 1 , no. 30 .

74 For in-depth detail in the planning and execution of the assassination, see Martha Doggett, A Death Foretold: The Jesuit Murders in El Salvador (Washington, DC: Georgetown University Press, 1993); Theresa Whitfield, Paying the Price: Ignacio Ellacuría, and the Murdered Jesuits of El Salvador (Philadelphia: Temple University Press, 1994); and Robert Lassalle-Klein, Blood and Ink: Ignacio Ellacuría, Jon Sobrino, and the Jesuit Martyrs of the University of Central America (Maryknoll, NY: Orbis Books, 2014): 174-80.

75 See Jon Sobrino, S.J., Companions of Jesus: The Jesuit Martyrs of El Salvador (Maryknoll, NY: Orbis Books, 1990), 6o-61.

76 See Ignacio Ellacuría: Essays on History, Liberation, and Salvation, ed. Michael E. Lee (Maryknoll, NY: Orbis Books, 2013) and Ignacio Ellacuría, S.J., Freedom Made Flesh: The Mission of Christ and His Church, trans. John Drury (Maryknoll, NY: Orbis Books, 1976). For the best secondary literature, see Kevin F. Burke, S.J., The Ground beneath the Cross: The Theology of Ignacio Ellacuría (Washington, DC: Georgetown University Press, 200o); Kevin F. Burke, S.J. and Robert Lassalle-Klein, eds. The Love that Produces Hope: The Thought 
the only intellectual who has worked for justice through his writings, but his untimely and violent death make his writings all the more powerful and prophetic. Ellacuría's writings belong in the genre known as liberation theology. Along with Gustavo Gutiérrez, O.P. (b.1928), Leonardo Boff (b.1938), and fellow Jesuits Juan Luis Segundo (1925-96) and Jon Sobrino (b.1938), Ellacuría would, by any standard, be counted as one of the most consequential figures in Latin American liberation theology. His death, though, marks Ellacuría's witness in a category of its own. In perhaps Ellacuría's most influential address, he spoke of the mission of Catholic institutions of higher education during his keynote remarks at the June 12, 1982 commencement of Santa Clara University. ${ }^{77}$ During that important address, Ellacuría made it clear that Catholic colleges and universities did not exist only as places of intellectual endeavor (although they certainly strove to be that); rather, they were institutions that enabled women and men to reach their full potential as moral individuals. Or, in his own eloquent words: "Reason and faith merge, therefore, in confronting the reality of the poor. Reason must open its eyes to the fact of suffering. Faith, which is sometimes scandalous to those without it, sees in the weak of this world the triumph of God, for we see in the poor what salvation must mean and the conversion to which we are called."78 Such a marriage between faith and reason is at the heart of Jesuit higher education today.

\subsection{Dean Brackley (1946-2011) and Greg Boyle (b.1954)}

One of the most interesting and heroic members of the UCA faculty since the 1989 martyrdom was Dean Brackley, S.J. Brackley was one of the Jesuits who immediately substituted for their slain brethren. Without question, there was the obvious concern that further violence would be carried out and simply taking the job was putting one's life in grave danger. Brackley's constant witness was buoyed not only by his scholarship, ${ }^{79}$ but also by his personal interactions with countless college and university students traveling to the UCA from the

of Ignacio Ellacuría (Collegeville, MN: Liturgical Press, 2006); J. Matthew Ashley, Kevin F. Burke, S.J., and Rodolfo Cardenal, S.J., eds., A Grammar of Justice: The Legacy of Ignacio Ellacuría (Maryknoll, NY: Orbis Books, 2014); John Hasset and Hugh Lacey, eds. Towards a Society that Serves Its People: The Intellectual Contribution of El Salvador's Murdered Jesuits (Washington, DC: Georgetown University Press, 1991); and Michael E. Lee, Bearing the Weight of Salvation: The Soteriology of Ignacio Ellacuría (New York: Crossroad, 2009).

77 Ellacuría was also awarded an honorary degree on the occasion.

$7_{8}$ Ignacio Ellacuría, "The Task of a Christian University," in Sobrino, Companions of Jesus, 149-50.

79 See, for example, Dean Brackley, S.J., Divine Revolution: Salvation and Liberation in Catholic Thought (Maryknoll, NY: Orbis Books, 1996), and Brackley, The Call to Discernment in 
United States, either as part of an immersion project or a study abroad program. Through this work, Brackley was able to introduce a new reality to visiting students who were unfamiliar with the reality in El Salvador.

In recent years, if one were to identify a single Jesuit that has travelled to the largest number of Jesuit colleges and universities to talk about the Jesuit understanding of social justice, it would be Greg Boyle, S.J. (b.1954). The last five general congregations, however, are almost never the subject of Boyle's public lectures and keynote addresses when he is being honored at this commencement or that convocation. Rather, Boyle focuses on his own experiences as founder of Homeboy Industries, the world's largest gang-member reintegration organization. Boyle's method of enacting social justice proceeds with the following basic understanding: "Our common human hospitality longs to find room for those who are left out. It's just who we are if allowed to foster something different, something more greatly resembling what God had in mind. Perhaps, together, we can teach each other how to bear the beams of love, persons becoming persons, right before our eyes." ${ }^{80}$ Before founding Homeboy Industries, Boyle served for years as the pastor of Dolores Mission church, one of the poorest parishes in the Archdiocese of Los Angeles. ${ }^{81}$ Even if the first Jesuits ministered to those on the margins of society before the terminology for social justice came about, ${ }^{82}$ today Boyle represents a faction of Jesuits ministering to those on the margins of society, with social justice at the heart of their ministry.

\subsection{Jesuit Higher Education and Social Justice}

Since GC 32, Jesuit higher education has taken a different stand on issues of social injustice through their curricula, their mission statements, and extracurricular interests of their students. The reasons, according to John Kavanaugh, S.J., are quite fundamental: "Human dignity and emancipation are at the genesis of all authentic education, wherein the truth of human personhood elaborated in literature, science, professions, art, and discourse yields a greater

Troubled Times: New Perspectives on the Transformative Wisdom of Ignatius of Loyola (New York: Crossroad, 2004).

8o Gregory Boyle, S.J., Tattoos on the Heart: The Power of Boundless Compassion (New York: Free Press, 2010), xiv-xv.

81 For more on these years, see Celeste Fremon, Father Greg and the Homeboys: The Extraordinary Journey of Father Greg Boyle and His Work with the Latino Gangs of East L.A. (New York: Hyperion, 1995).

82 See O'Malley, First Jesuits, 165-99. 
and richer range of human freedom." ${ }^{83}$ Therefore, not only is social justice at the very heart of Jesuit higher education, but there is also a reminder that Jesuit higher education is, by its very nature, multidisciplinary. Justice is not relegated only to classroom sessions of theology and philosophy but must be part and parcel of every academic area ${ }^{84}$ How does this commitment to a faith that does justice manifest itself? Most concretely, as the former president of the Association of Jesuit Colleges and Universities, Charles Currie, S.J., puts it, "In addition to community service opportunities, service learning - which links service activity with reflection and classroom analysis—is becoming a staple in the academic life of our schools." ${ }^{\prime 5}$

The commitment to which Currie alludes is in direct response to GC $3^{2}$ Decree 4 and GC 34 Decree 3. As Arthur McGovern, S.J., acknowledges, Currie's description of a newfound focus on community service and service learning is only part of the process of a renaissance in Jesuit higher education. McGovern explains, "GC 34 implies a need for social analysis when it calls on Jesuits to address 'structural' changes." ${ }^{86}$ Even this further commitment, though, is not sufficient for everyone, nor is it meant to be something with which Jesuits and their lay colleagues should simply be satisfied. ${ }^{87}$ Rather, the Jesuit commitment to social justice in higher education should never settle with its current status and rest on its laurels, which include the Cristo Rey model of education, ${ }^{88}$ as well as the Arrupe College at Loyola University, Chicago. ${ }^{89}$ It should, however, be rightly proud of its alumni who have taken the call for

83 John F. Kavanaugh, S.J., "Jesuit Education and Social Justice in Theory and Practice," in Jesuit Higher Education: Essays on an American Tradition of Excellence, ed. Rolando E. Bonachea (Pittsburgh: Duquesne University Press, 1989), 168-75, here 173.

84 For examples of many areas of Jesuit education, see Traub, A Jesuit Education Reader.

85 Charles L. Currie, S.J., "Greetings," in Jesuit Education 21: Conference Proceedings on the Future of Jesuit Higher Education, ed. Martin R. Tripole, S.J. (Philadelphia: Saint Joseph's University Press, 2000), 3-7, here 5 .

86 Arthur F. McGovern, S.J., "A Faith-Justice Look at GC 34," in Promise Renewed:Jesuit Higher Education for a New Millennium, ed. Martin R. Tripole, S.J. (Chicago: Loyola University Press, 1999), 144-54, here 146.

87 For a robust discussion and debate, see the contributions of Robert J. Araujo, S.J., Denise Carmody, Francis X. Clooney, S.J., and James L. Marsh, "What Is Jesuit Higher Education: The Service of Faith and the Promotion of Justice?," in Tripole, Jesuit Education 21, 24-54.

88 See G. R. Kearney, More Than a Dream: The Cristo Rey Story: How One School's Vision is Changing the World (Chicago: Loyola University Press, 2008) and Megan Sweas, Putting Education to Work: How Cristo Rey High Schools are Transforming Urban Education (New York: Harper Collins, 2014).

89 See Stephen N. Katsouros, S.J., Come to Believe: How the Jesuits Are Reinventing Education (Again) (Maryknoll, NY: Orbis Books, 2017). 
social justice seriously, on both an intellectual and emotional level..$^{90}$ Nevertheless, as the number of professed Jesuit educators in colleges and universities continue to diminish, their lay colleagues must take up the mantle to make their students aware that social justice is at the very heart of their education, which will hopefully continue for the rest of their lives.

\section{Jesuits in Africa and Asia: Inculturation, Interreligious Dialogue, and Social Justice}

As I hope I have made clear thus far, not all social justice looks the same. One particular way that the Jesuits have carried out social justice is through inculturation in various parts of the world. Perhaps nowhere does this practice carry such a history as in African and Asian nations. In Africa, Jesuits have engaged in inculturation "in the context of missionary Christianity." ${ }^{91}$ Today, many nativeborn African Jesuits minister to people in their own lands. Social justice is at the heart of their work. In particular, the African Jesuit AIDS Network has become a major part of the Jesuit mission to work for a more just society on that continent. ${ }^{92}$ The Jesuits have made clear that social injustice is at the heart of the spread of AIDS in sub-Saharan Africa, and that the continued spread of the disease allows social injustice to spread in a cyclical fashion. Therefore, the work of the Jesuits to cease the spread of the disease is a major component of social justice work. The work of the Society in Asia has taken on the problems of social injustice as well. ${ }^{93}$ Especially important to these Jesuits has been ecological care, without which social justice as a whole cannot flourish. While, as I have noted, this is a burgeoning issue throughout global Catholicism in light of Laudato si', the Asian Jesuits have focused on this issue for even longer, responding to the deleterious effects in their own communities. Jesuit social centers play an important role in how the Society carries out actions for

9o One such group of alumni would surely be those who join the Jesuit Volunteer Corps. See Raymond A. Schroth, S.J., The American Jesuits: A History (New York: New York University Press, 2007), 266-70.

91 Agbonkhianmeghe E. Orobator, S.J., Theology Brewed in an African Pot (Maryknoll, NY: Orbis Books, 2008), 127.

92 For a full description of their apostolate, see http://www.ajanweb.org (accessed September 19, 2019).

93 For more on their work, see https://jcsaweb.org/ministries/social-action/ (accessed September 19, 2019). 
social justice in Asia. ${ }^{94}$ These centers have practiced interreligious dialogue and cooperation in order to carry out work to ban landmines, bring about justice for refugees, and move toward a more peaceful society.

\section{Conclusion}

At the risk of making it seem as though the Society of Jesus has always been perfect when it comes to promoting social justice, it bears remembering that until 1975 and the conclusion of GC 32 , the Jesuits had not yet come to a definitive conclusion on how best to enact social justice in their ministries. Even then, as I have already noted, there was no little dissent among the ranks of Jesuits throughout the world as to what social justice entails and whether or not the delegates of GC 32 had erred in including it as a fundamental aspect of the Jesuit charism. In fact, at times in their history, Jesuits have (by their own admission) utterly failed to enact justice in society. The most noteworthy of these failures is that Jesuits of the Maryland province owned slaves in the eighteenth and nineteenth centuries. ${ }^{95}$ While the Jesuits have gone to some lengths to try and repent of their sins and injustices, this remains one of the most significant tarnishes on the order.

In addition to slaveholding, Jesuits have not always been at the forefront of fair and just treatment of women. Most fundamentally, women have never been admitted as members in the Society of Jesus, unlike other major religious orders. ${ }^{96}$ That point notwithstanding, the Ignatian charism is certainly influential in a good number of women's religious orders. ${ }^{97}$ Even individual Jesuits who have long been praised for their commitment to minority groups have

94 See Jesuit Social Centres: Structuring the Social Apostolate (Rome: Social Justice Secretariat, 2005).

95 See Thomas Murphy, S.J., Jesuit Slaveholding in Maryland, 1717-1838 (New York: Routledge, 2001). For the "Georgetown Slavery Archive," see http://slaveryarchive.georgetown.edu (accessed September 19, 2019).

96 See Lacouture, Jesuits, 136-6o; Lisa Fullam, "Juana, S.J.: The Past (and Future?) Status of Women in the Society of Jesus," Studies in the Spirituality of Jesuits 31, no. 5 (1999): 1-43; Gemma Simmonds, C.J., "Women Jesuits," in The Cambridge Companion to the Jesuits, ed. Thomas Worcester, S.J. (Cambridge: Cambridge University Press, 2008), 120-35. For two exceptions to this enduring rule, see Simmonds, "Women Jesuits," 122.

97 See Margaret Gorman, R.S.C.J., "The Influence of Ignatian Spirituality on Women's Teaching Orders in the United States," in The Jesuit Tradition in Education and Missions, ed. Christopher Chapple (Scranton, PA: University of Scranton Press, 1993), 182-202. 
recently come under fire in renewed examinations of their lives and actions. ${ }^{98}$ Finally, the Jesuits have not paid nearly enough attention to the topic of environmental degradation, investments, or unions for affiliate faculty. The first mention of ecology in the decrees of Jesuit general congregations, for instance, did not appear until GC 34 Decree 20, nos. 430-32, the concluding paragraphs of the documentation. ${ }^{99}$ As I alluded to above, however, the Jesuits do focus more on the topic in GC 36 . There is a welcome addition to Jesuit literature on the ecological crisis: the first Jesuit pope, Francis, promulgated his social encyclical Laudato si' on the topic of our common home in $2015 .{ }^{100}$

Even if the contributions of Pope Francis have been groundbreaking in the Jesuit (and Catholic) treatment of ecological issues, there remains a question as to the extent that the Jesuits' own recent emphasis on the natural environment motivated Francis in the drafting of Laudato si'. In fact, one might well argue that Franciscan spirituality is much closer to the heart of the document than is Ignatian spirituality. For example, Saint Francis of Assisi's (1182-1226) "Canticle of the Creatures" opens the encyclical. Other than the occasions when he cites himself in the document, Pope Francis only cites two other Jesuits. ${ }^{101}$ However, it is impossible to overlook the foundational impact his Jesuit formation has on Pope Francis in all of his writings and actions. In Laudato si', Francis displays the Ignatian worldview throughout his writing. In particular, "he warns against 'any disordered use of things.".102

Jesuits themselves have contributed to social injustice at times by failing to live up to the standards of their founder. In fact, many Jesuits themselves have been guilty of using other parts of the created order (human and not) in a disordered way. One prominent, and particularly painful, example of that disordered use is the recently-published list of Jesuits from the United States who have been credibly accused of sexually abusing minors. ${ }^{103}$ While the human finitude and sinfulness of its members is one limitation to the Jesuits' social justice initiatives moving forward, another practical concern will be

98 See Katie M. Grimes, "Racialized Humility: The White Supremacist Sainthood of Peter Claver, SJ," Horizons 42, no. 2 (2015): 295-316.

99 See Padberg, Jesuit Life and Mission Today, 637.

100 Pope Francis, Laudato si' (May 24, 2015); http://w2.vatican.va/content/francesco/en/ encyclicals/documents/papa-francesco_20150524_enciclica-laudato-si.html (accessed September 12, 2019).

101 See Pope Francis, Laudato si', nos. 83 (n. 53) and 149 (n. 117). The Jesuits in question are Pierre Teilhard de Chardin (1881-1955) and Juan Carlos Scannone (b.1931).

102 Paul L. Younger, "Ignatian Spirituality and the Ecological Vision of Laudato si," The Way 54, no. 4 (2015): 57-67, here 64. The citation comes from Laudato si', no. 69.

103 See http://jesuits.org/news-detail?tn=news-20190115101325 (accessed September 12, 2019). 
the diminishing number of professed members of the order. As the number of Jesuits continues to decrease, it may become increasingly difficult to carry out the social justice agenda. Jesuits and their lay colleagues must inculcate in students at their institutions the radical importance of a life committed to creating a more just society for all people. While all of these issues, and more, remain areas of potential growth for the Society of Jesus, the order would do well to follow in the footsteps of their confrere, Pope Francis, and continue working to move to the peripheries of society. In so doing, the work of Jesuits and their lay collaborators in social justice apostolates will continue to flourish and improve. 